\title{
ROLA EDUKACJI EKONOMICZNEJ W KSZTAŁTOWANIU STABILNOŚCI SYSTEMU FINANSOWEGO
}

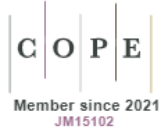

\section{Eleonora Ratowska-Dziobiak* \\ THE ROLE OF ECONOMIC EDUCATION IN THE CONTEXT OF SHAPING THE STABILITY OF THE FINANCIAL SYSTEM}

\begin{abstract}
An efficiently operating financial system is considered as an integral part of a well-functioning economy. It is the mechanism by which services are provided that allow the flow of purchasing power. Thus, this system creates the foundations of activity for entities using money, enabling the conclusion of economic transactions in which money performs various functions. The result of the existence of this system is the possibility of co-creation of money by non-financial economic entities (enterprises and households) and the flow of cash between them. In the light of many transformations taking place in the financial system, it is extremely important to ensure its stability. A properly functioning financial system significantly supports the achievement of the main goals of the central bank - maintaining a stable level of prices, and thus creating the basis for achieving long-term economic growth. Educational activities are of great importance in ensuring the stability of the financial system. The aim of the article is to present the role of economic education among young people, thanks to which they can better understand the complexities of the functioning of the financial system, the importance of its stability and prepare to make more conscious decisions as fully-fledged participants of the financial market. Understanding the specificity of the available financial instruments enables the minimalization of the risk associated with their selection / purchase. The accuracy of decisions made in adulthood depends on the knowledge of basic economic issues and the awareness of potential threats.
\end{abstract}

Keywords: economic education, stability, financial system, financial market, financial services.

JEL Class: G53, 125, D83, E58.

\footnotetext{
*Dr, Wydział Ekonomiczno-Socjologiczny, Uniwersytet Łódzki, e-mail: eleonora.ratowska@uni.lodz.pl.
} 


\section{WSTĘP}

Sprawnie działający system finansowy uznawany jest za nieodłączny element dobrze funkcjonującej gospodarki. Jest on mechanizmem, dzięki któremu świadczone są usługi pozwalające na przepływ siły nabywczej (Polański, 2016: 17). Rezultatem istnienia tego systemu jest możliwość współtworzenia pieniądza przez niefinansowe podmioty gospodarcze i przepływu strumieni pieniężnych między nimi (Dębski, 2010: 15). W świetle wielu przekształceń dokonujących się w systemie finansowym niezmiernie ważne jest dbanie o jego stabilność. Właściwie funkcjonujący system finansowy w istotny sposób wspiera realizację głównych celów banku centralnego - utrzymania stabilnego poziomu cen, a przez to tworzenia podstaw do osiągnięcia długookresowego wzrostu gospodarczego.

W prowadzonej analizie przyjęto następującą hipotezę badawczą: Stabilność systemu finansowego jest zdeterminowana przez poziom edukacji ekonomicznej. Zmierzając do jej weryfikacji, autorka podejmuje próbę znalezienia odpowiedź na następujące pytania badawcze: ność?

1) Jak skonstruowany jest system finansowy i od czego zależy jego stabil-

2) Jakie działania podejmuje się na rzecz budowania stabilnego systemu finansowego?

3) W jaki sposób edukacja ekonomiczna może wpływać na stabilność systemu finansowego?

4) Które inicjatywy edukacyjne mogą przynieść pożądane efekty z punktu widzenia stabilności systemu finansowego?

W badaniu skorzystano ze studiów literaturowych, wyników diagnozy opracowanej przez NBP w roku 2014 oraz 2018 (dotyczącej stanu wiedzy i świadomości ekonomicznej dzieci i młodzieży w Polsce), rozmów z 100 przedszkolakami, 120 uczniami i 20 nauczycielami w wybranych placówkach edukacyjnych w Łodzi w latach 2016-2020 (w formie zogniskowanych wywiadów grupowych).

\section{POJĘCIE SYSTEMU FINANSOWEGO. JEGO STRUKTURA I FUNKCJE}

Chcąc określić rolę edukacji ekonomicznej w kształtowaniu stabilności systemu finansowego należy wyjaśnić, czym jest system finansowy. W literaturze występuje wiele różnorodnych ujęć analizowanego zagadnienia. Według A. MatysekJędrych (2007: 39) występujące między nimi różnice wynikają z innego postrzegania funkcji pełnionych przez system finansowy. Próbując dokonać pewnej ich systematyki, można posłużyć się klasyfikacją zaproponowaną przez Tyrell'a i Schmidta (2001: 5-12). Zaprezentowane w tabeli 1 podejścia nie uwzględniają wszystkich ujęć badanego zagadnienia. 
Tabela 1. Przegląd najważniejszych ujęć zagadnienia system finansowy

\begin{tabular}{|c|c|c|c|}
\hline \multicolumn{2}{|c|}{ Podejście } & Charakterystyka & $\begin{array}{l}\text { Rozumienie systemu } \\
\text { finansowego }\end{array}$ \\
\hline \multicolumn{2}{|c|}{ Instytucjonalne } & $\begin{array}{l}\text { - ujęcie systemu finansowego } \\
\text { z punktu widzenia instytucji } \\
\text { finansowych } \\
\text { - skierowanie uwagi na opis oraz } \\
\text { klasyfikację instytucji } \\
\text { - przedmiotem analizy jest często } \\
\text { wybrana cecha instytucji (np. sto- } \\
\text { pień konkurencyjności, ochrona } \\
\text { praw inwestora, jakość regulacji } \\
\text { finansowych) }\end{array}$ & $\begin{array}{l}\text { - zbiór określonych } \\
\text { i zaklasyfikowanych do } \\
\text { odrębnych grup instytucji } \\
\text { finansowych }\end{array}$ \\
\hline \multirow{2}{*}{ 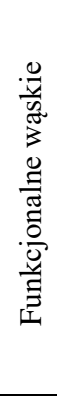 } & monetarne & $\begin{array}{l}\text { - analiza systemu finansowego } \\
\text { głównie w kontekście roli pełnio- } \\
\text { nej przez system bankowy (bank } \\
\text { centralny i banki komercyjne) }\end{array}$ & $\begin{array}{l}\text { - mechanizm zaopatrywa- } \\
\text { nia gospodarki realnej } \\
\text { w pieniądz }\end{array}$ \\
\hline & $\begin{array}{c}\text { oparte na } \\
\text { pośrednictwie }\end{array}$ & $\begin{array}{l}\text { - analiza systemu finansowego } \\
\text { z perspektyw dwóch najważniej- } \\
\text { szych funkcji: pośredniczenia } \\
\text { oraz transformacji, której podle- } \\
\text { gają: ryzyko, pieniądz - kwota, } \\
\text { czas trwania, przestrzeń, waluta } \\
\text { (Janc, 2004: 4-5) }\end{array}$ & $\begin{array}{l}\text { - mechanizm pośrednicze- } \\
\text { nia między podmiotami } \\
\text { nadwyżkowymi } \\
\text { a podmiotami deficyto- } \\
\text { wymi sfery realnej gospo- } \\
\text { darki }\end{array}$ \\
\hline \multicolumn{2}{|c|}{ Funkcjonalne szerokie } & $\begin{array}{l}\text { - analiza systemu finansowego } \\
\text { w kontekście jego funkcji } \\
\text { - względna stałość i porównywal- } \\
\text { ność funkcji poszczególnych na- } \\
\text { rodowych systemów finansowych }\end{array}$ & $\begin{array}{l}\text { - sieć rynków finansowych, } \\
\text { pośredników finanso- } \\
\text { wych oraz innych instytu- } \\
\text { cji, dzięki którym realizo- } \\
\text { wane są wszystkie plany } \\
\text { finansowe gospodarstw } \\
\text { domowych, przedsię- } \\
\text { biorstw i rządu } \\
\end{array}$ \\
\hline \multicolumn{2}{|r|}{ Systemowe } & $\begin{array}{l}\text { - analiza systemu finansowego pod } \\
\text { względem związków między po- } \\
\text { szczególnymi elementami sys- } \\
\text { temu oraz ich wpływu na funkcjo- } \\
\text { nowanie całego systemu finanso- } \\
\text { wego }\end{array}$ & $\begin{array}{l}\text { - uporządkowany zbiór } \\
\text { komplementarnych } \\
\text { i możliwie spójnych ele- } \\
\text { mentów lub podsyste- } \\
\text { mów }\end{array}$ \\
\hline
\end{tabular}

Źródło: opracowanie własne na podstawie A. Matysek-Jędrych, 2007: 40.

Dostrzec można dwie grupy podejść do pojęcia systemu finansowego. Podstawowa różnica między nimi polega na odmiennym postrzeganiu głównych elementów tego systemu. W definicjach należących do 1 grupy uwypuklone są aspekty strukturalno-instytucjonalne. Zaliczają się do niej podejście instytucjo- 
nalne i systemowe. W definicjach w ramach 2 grupy wyróżniającym się elementem są funkcje systemu finansowego, charakterystyczne dla podejścia monetarnego i opartego na pośrednictwie oraz funkcjonalnego szerokiego.

Chcąc uwzględnić najważniejsze cechy poszczególnych ujęć, a także zwracając uwagę zarówno na kwestię budowy systemu jak i zależności między jego elementami, można posłużyć się następującą definicją: „,system finansowy jest układem wzajemnie powiązanych instytucji finansowych, rynków finansowych oraz elementów infrastruktury systemu finansowego; poprzez ten układ podmioty sfery realnej (przede wszystkim gospodarstwa domowe, przedsiębiorstwa i rząd) mogą pozyskiwać fundusze, inwestować oszczędności oraz zaspokajać pozostałe potrzeby związane z finansową sferą funkcjonowania" (Matysek-Jędrych, 2007: 41). W podobny, kompleksowy sposób do zagadnienia system finansowy podchodzi S. Owsiak (2015: 234), który zdefiniował go jako „zespół logicznie ze sobą powiązanych form organizacyjnych, aktów prawnych, instytucji finansowych i innych elementów umożliwiających podmiotom nawiązanie stosunków finansowych w sektorze realnym i sektorze finansowym".

W oparciu o przytoczone definicje i podejścia do badanego zagadnienia systemowi finansowemu można przypisać trzy podstawowe funkcje: monetarną ${ }^{1}$, kapitałowo-redystrybucyjną ${ }^{2}$ i kontrolną (Pietrzak i in., 2016: 18).

W bardziej szczegółowy sposób do tej kwestii podchodzi Stiglitz (1992: 163), który zwraca uwagę na:

- transferowanie zasobów kapitału od tych podmiotów, które go posiadają, do tych, które chcą te zasoby wykorzystać,

- gromadzenie kapitału (w jednej puli),

- wybór projektów (pozwalających na zainwestowanie zgromadzonych oszczędności),

- monitorowanie wykorzystania środków,

- zapewnienie realizacji zapisów umowy,

- transferowanie, dzielenie i łączenie (pooling) ryzyka,

${ }^{1}$ Rozumiana jako dostarczenie podmiotom niefinansowym podstawowego dla funkcjonowania rynkowej gospodarki instrumentu, jakim jest pieniądz i umożliwienie jego obiegu.

${ }^{2} \mathrm{~W}$ ramach tej funkcji system finansowy usprawnia przepływ wolnych środków pieniężnych od podmiotów dysponujących nimi do podmiotów, które chciałyby z nich korzystać. W ten sposób system ten pełni rolę mechanizmu zamiany dobrowolnych oszczędności i środków wymuszonych za pomocą instrumentów fiskalnych (funduszy publicznych) w inwestycje sfery realnej, a także w konsumpcję publiczną (zbiorową) i indywidualną. Uzyskane środki służą wówczas finansowaniu dóbr publicznych, usług i świadczeń społecznych.

${ }^{3}$ System finansowy sprawuje kontrolę nad strumieniami pieniężnymi, zwłaszcza nad środkami zainwestowanymi, pożyczonymi i redystrybuowanymi w przeszłości. W przypadku omawianej funkcji chodzi o wszelkie usługi, które umożliwiają weryfikację efektywności wykorzystania majątku (rzeczowego i ludzkiego) i środków finansowych (z uwzględnieniem funduszy publicznych) i badanie wpływu instytucji i rynków finansowych na przedsiębiorstwa i gospodarstwa domowe. 
- dywersyfikowanie (rozumiane również jako oszczędzanie na kosztach transakcyjnych, w tym kosztach informacji),

- umożliwienie przeprowadzenia transakcji.

Wartym odnotowania jest także podział funkcji systemu finansowego autorstwa Mertona i Bodie (1995: 5):

- zapewnienie sposobów transferu środków ekonomicznych w czasie i przestrzeni,

- zapewnienie skutecznych metod i procedur zarządzania ryzykiem,

- zapewnienie sposobów rozliczania i dokonywania płatności,

- zapewnienie mechanizmów gromadzenia środków (pieniężnych) i dzielenia własności przedsiębiorstw (podział środków na udziały w różnych przedsięwzięciach),

- zapewnienie informacji o cenie, co pozwala na koordynowanie zdecentralizowanego procesu podejmowania decyzji w różnych sektorach gospodarki,

- zapewnienie sposobów pokonywania problemu niedostatku motywacji w sytuacji występowania zjawiska asymetrii informacji.

Niezależnie od proponowanych klasyfikacji i nazewnictwa funkcji systemu finansowego na uwagę zasługuje fakt dostrzeżenia ich wielości. Podjęcie badań w tym zakresie zapoczątkowało dyskusję na temat złożoności zagadnienia systemu finansowego i jego znaczenia dla prawidłowego funkcjonowania gospodarki. System finansowy sprzyja koordynacji mikroekonomicznych procesów decyzyjnych oraz działalności ekonomicznej opartej na zasadzie społecznego podziału pracy. Dostarczane przez system finansowy usługi sprzyjać mają rozwojowi sfery realnej. Umożliwia mobilizację oszczędności oraz ich bardziej efektywną alokację. Pozwala na redukcję ryzyka i dywersyfikację portfela aktywów (Matysek-Jędrych, 2007: 41). Od sprawności systemu finansowego zależy, czy będzie on siłą napędzającą rozwój gospodarczy, czy stanie się źródłem ekonomicznej niestabilności.

\section{RYNKI, INSTRUMENTY ORAZ INSTYTUCJE FINANSOWE - ICH ZNACZENIE I ROZWÓJ}

Powstanie rynku finansowego jest związane z pojawieniem się pieniądza, który ułatwia rozliczenia między kontrahentami i stanowi kluczowy element gospodarki pieniężnej (Dębski, 2010: 15; Howells and Bain, 1998: 3-5). Transakcje na rynku finansowym są równoznaczne z czasowym przekazaniem środków na rzecz pożyczkobiorcy, pod warunkiem zwrotu kwoty powiększonej o odpowiedni procent w określonym terminie lub też uzyskania określonej kwoty zwrotu w przyszłości. Przedmiotem obrotów na tym rynku są różnego rodzaju instrumenty finansowe ${ }^{4}$,

\footnotetext{
${ }^{4}$ M.in. weksle, certyfikaty, bony, obligacje, akcje, opcje, depozyty, ubezpieczenia, itp.
} 
występują na nim aktywa o zróżnicowanych parametrach ${ }^{5}$ (Pietrzak i in., 2016: 25-27).

Rynek finansowy jest pojęciem bardzo obszernym, wskazującym na jego ogromną złożoność i wielopłaszczyznowość. Może być bowiem rozpatrywany z punktu widzenia jego zasięgu terytorialnego, skali, formy obrotów, formy organizacyjnej rynku, a także dostępnych na nim instrumentów finansowych (Dębski, 2010: 21). Możliwość zaliczenia niektórych z nich do różnych segmentów sygnalizuje, że obowiązujące podziały rynku finansowego nie są doskonałe i dostatecznie precyzyjne (Jajuga i in., 1998: 73).

Ogromne znaczenie przypisywane rynkom finansowym w systemie finansowym oraz w całej gospodarce państwa wynika stąd, że rynki te przyczyniają się do przekształcenia oszczędności w kapitał, który pełni bardzo aktywną rolę, wywołując wzrost i rozwój gospodarczy (Rose, 1992: 13). Rynek finansowy sprzyja także podniesieniu efektywności wykorzystywania zasobów w gospodarce. Dzięki jego istnieniu możliwy jest transfer zasobów rzeczowych do możliwie najlepszych zastosowań, co przyspiesza rozwój gospodarczy (Czekaj, 2008: 7).

Instytucje finansowe zmierzają do optymalnej alokacji kapitału: od podmiotów dysponujących nadwyżkami, zainteresowanych mniejszym lub większym zwrotem z inwestycji do podmiotów/regionów o rosnącym zapotrzebowaniu na kapitał inwestycyjny, będących w fazie przyspieszonego wzrostu (Zombirt, 2011: 85). Rosnąca skłonność do oszczędzania, będąca efektem bogacenia się społeczeństwa, wzrostu uprzemysłowienia, zmian demograficznych i socjologicznych, wpływa na urozmaicenie oferty wszystkich instytucji finansowych. Klienci mają do wyboru coraz większy wachlarz usług finansowych. Ich rynek jest jednym z najszybciej rozwijających się sektorów polskiej gospodarki, do czego przyczynił się sam proces transformacji gospodarczej oraz przystąpienie Polski do Unii Europejskiej.

W obliczu dokonujących się przekształceń całego systemu finansowego zmianie ulega także znaczenie poszczególnych instytucji. Odchodzą one od wąskiej specjalizacji, dokonują zmian profilu swej działalności, tworzą różnego rodzaju powiązania (alianse). Wzbogacają swą ofertę produktową oraz wykorzystują zróżnicowane kanały dystrybucji. Starają się podążać za nowymi warunkami rynkowymi, tak by móc lepiej zrozumieć i zaspokoić potrzeby klientów.

Z drugiej jednak strony instytucje cechuje swego rodzaju „kruchość”, niestabilność i podatność na znaczne wahania cen/kursów. U podłoża tych właściwości leży przede wszystkim asymetria informacyjna. Tak nierównomierny rozkład towarzyszy zwykle wszelkim umowom/transakcjom. Jednak szczególnie widoczny jest w odniesieniu do instrumentów finansowych, mających niematerialny, nienamacalny charakter. Strony danej transakcji dysponują zróżnicowanym zakresem

\footnotetext{
${ }^{5} \mathrm{~Np}$. termin zapadalności, ryzyko, czy różny poziom dochodów, które generują.
} 
informacji, a nabywca często staje przed niewiadomą, jak jego środki pieniężne zostaną faktycznie wykorzystane, z jakim ryzykiem musi się liczyć i jakie korzyści może odnieść (Pietrzak i in., 2016: 25-27; Anginer et al., 2014: 1-26). Niedostateczna wiedza ekonomiczna może sprzyjać podejmowaniu błędnych decyzji przez konsumentów. Na uwagę zasługuje także nie zawsze rzetelna i etyczna postawa pracowników instytucji finansowych, którzy mogą przekazywać swoim klientom niepełną informację dotyczącą potencjalnego ryzyka wynikającego z zawartej umowy. Z tego też względu ogromne znaczenie ma działalność edukacyjna różnych podmiotów (NBP, Rzecznika Finansowego, KNF, UOKiK, PTE, itp.), dzięki której dzieci i młodzież mogą lepiej poznać specyfikę funkcjonowania rynku finansowego (o czym szerzej traktuje pkt. 4). Stwarza to szansę na uniknięcie niewłaściwych wyborów w życiu dorosłym, co przy dużej liczbie nieświadomych i niewyedukowanych konsumentów mogłoby się niekorzystnie odbić na stabilności systemu finansowego.

\section{STABILNOŚĆ SYSTEMU FINANSOWEGO ORAZ DZIAŁALNOŚĆ NBP NA JEJ RZECZ}

W świetle wielu przekształceń dokonujących się w systemie finansowym niezmiernie ważne jest dbanie o jego stabilność. Rozumiana jest ona jako „stan, w którym system finansowy pełni swoje funkcje w sposób ciągły i efektywny, nawet w przypadku wystąpienia nieoczekiwanych i niekorzystnych zaburzeń o znacznej skali" (www6). Stabilny system finansowy jest zdolny do efektywnej alokacji zasobów, oceny i zarządzania ryzykiem finansowym, utrzymywania poziomu zatrudnienia bliskiego naturalnej stopie gospodarki oraz eliminowania względnych ruchów cen aktywów rzeczowych lub finansowych, które wpłyną na stabilność monetarną lub poziom zatrudnienia. Może amortyzować wstrząsy za pomocą mechanizmów samokorygujących. Stabilność finansowa ma kluczowe znaczenie dla wzrostu gospodarczego, ponieważ większość transakcji w gospodarce realnej odbywa się za pośrednictwem systemu finansowego (www7).

Czuwanie nad stabilnością systemu finansowego to jedno z zadań należących do Narodowego Banku Polskiego. Wypełniając konstytucyjny obowiązek, NBP opracowuje i realizuje założenia polityki pieniężnej. W art. 3 ust. 1 ustawy z dnia 29 sierpnia 1997 r. o Narodowym Banku Polskim (Dz.U. 2017, poz. 1373 z późn. zm.) podkreśla się, że ,podstawowym celem działalności NBP jest utrzymanie stabilnego poziomu cen, przy jednoczesnym wspieraniu polityki gospodarczej Rządu, o ile nie ogranicza to podstawowego celu NBP”. Zgodnie z przygotowaną przez Radę Polityki Pieniężnej Strategią Polityki Pieniężnej NBP zmierza do ustabilizowania inflacji na poziomie $2,5 \%$ z dopuszczalnym przedziałem wahań +/-1 punkt procentowy (www4). Poprzez zarządzanie rezerwami dewizowymi NBP zapewnia odpowiedni poziom bezpieczeństwa finansowego państwa, 
a dzięki emisji znaków pieniężnych zabezpiecza płynność obrotu gotówkowego (www4).

Stabilny system finansowy w istotny sposób wspiera realizację głównych celów banku centralnego - utrzymania stabilnego poziomu cen, a przez to tworzenia podstaw do osiągnięcia długookresowego wzrostu gospodarczego. Zakłócenia w pracy systemu finansowego i zaburzenia efektywności świadczenia usług pośrednictwa finansowego negatywnie wpływają na sytuację przedsiębiorstw i gospodarstw domowych. Dlatego wiodące banki centralne prowadzą analizy i badania w tym zakresie oraz publikują raporty o stabilności. Celem tych działań jest dostarczanie informacji o czynnikach ryzyka dla stabilności oraz ocena odporności systemu finansowego na zaburzenia. Upowszechnienie tego rodzaju wiedzy ma sprzyjać utrzymaniu stabilności finansowej, m.in. dzięki lepszemu zrozumieniu skali i zakresu ryzyka w systemie finansowym. W ten sposób zwiększa się prawdopodobieństwo samoistnej korekty zachowań uczestników rynku finansowego podejmujących zbyt duże ryzyko, bez konieczności ingerencji podmiotów publicznych w mechanizmy rynkowe (www6). Dbając o stabilność systemu finansowego, NBP sprawdza, czy cały system wypełnia prawidłowo swoje kluczowe funkcje, analizuje i ocenia ewentualne zagrożenia. Wyniki analiz, wraz z rekomendacjami działań ograniczających zidentyfikowane ryzyko, są publikowane w czerwcu i grudniu każdego roku w Raporcie o stabilności systemu finansowego, począwszy od 2001 r. (www6).

W ramach pełnionych funkcji nadzorczych i regulacyjnych NBP dba o płynność, sprawność i bezpieczeństwo systemu płatniczego. Przyczynia się również do rozwoju systemu bankowego (art. 3 ust. 2 pkt 6a i 6 ustawy o NBP), który odgrywa kluczową rolę $\mathrm{w}$ finansowaniu gospodarki i rozliczeniach pieniężnych (www4). Nieodpowiednia jego struktura może hamować rozwój gospodarczy kraju lub przyczynić się do kryzysu finansowego czy zwiększać jego zasięg. Ograniczony dostęp do kredytów powoduje spadek inwestycji oraz produkcji, co sprzyja zmniejszeniu zatrudnienia oraz dochodów społeczeństwa.

Działając na rzecz stabilności krajowego systemu finansowego i jego rozwoju, Narodowy Bank Polski współpracuje z innymi instytucjami państwowymi, m. in.: Ministerstwem Finansów, Komisją Nadzoru Finansowego oraz Bankowym Funduszem Gwarancyjnym, z którymi NBP tworzy wspólnie sieć bezpieczeństwa finansowego. Instytucje te są reprezentowane w Komitecie Stabilności Finansowej, którego zadaniem jest koordynacja działań na rzecz utrzymania lub przywrócenia stabilności systemu finansowego w przypadku bezpośredniego zagrożenia kryzysem i w czasie jego trwania. Bierze także udział w pracach międzynarodowych instytucji działających na rzecz stabilności finansowej, np. Europejskiej Rady Ryzyka Systemowego (European Systemic Risk Board, ESRB). Z uwagi na liczne powiązania finansowe gospodarki polskiej i polskiego systemu finanso- 
wego z zagranicą (np. w ramach Unii Europejskiej) ten obszar współpracy odgrywa szczególne znaczenie. Pozwala to na identyfikację zewnętrznych zagrożeń dla stabilności polskiego systemu finansowego.

Na uwagę zasługują także podejmowane przez NBP działania o charakterze edukacyjnym, które także w istotny sposób mogą kształtować stabilność systemu finansowego (o czym szerzej jest mowa w punkcie 4).

\section{EDUKACJA FINANSOWA I JEJ ZNACZENIE W KSZTAtTOWANIU STABILNOŚCI FINANSOWEJ}

Edukacja finansowa to jeden $z$ bardzo istotnych elementów zdobywania wykształcenia przez człowieka. Składa się ona z wiedzy i umiejętności praktycznych, niezbędnych dla każdego uczestnika życia społecznego, dzięki którym będzie mógł on realizować swoje cele życiowe i zawodowe (Husiatyńska, 2018: 42). Pod pojęciem edukacji finansowej rozumie się działania, które służą upowszechnianiu wiedzy finansowej oraz wykształceniu pozytywnych nawyków, co przekłada się na podejmowanie właściwych decyzji w zakresie zarządzania pieniędzmi (Frączek, 2013: 124). Konsumenci mają szansę rozwinąć swoje umiejętności w zakresie analizy kosztów alternatywnych, korzyści i zagrożeń związanych z daną inwestycją oraz zwiększyć świadomość ryzyka finansowego (Frisancho, 2019: 6). Wiedzą, gdzie mogą szukać pomocy i jakie działania należy podejmować, aby poprawić sytuację finansową (Kuchciak, 2013: 67). Wyedukowana ekonomicznie osoba potrafi efektywnie zarządzać finansami osobistymi, jest świadomym klientem instytucji finansowych, znającym konsekwencje zadłużenia i braku oszczędności (Świecka, 2018: 4; Frisancho, 2019: 6).

Edukacja finansowa społeczeństwa stanowi obecnie istotny warunek rozwoju rynku finansowego. Świadomi finansowo konsumenci są w stanie korzystać z innowacji, do których mają obecnie coraz większy dostęp (www8). W świetle ciągle dokonujących się zmian należy mieć na uwadze fakt, że obecna młodzież w przyszłości, jako już osoby dorosłe, będzie prawdopodobnie korzystała z jeszcze bardziej wyszukanych produktów finansowych (Frisancho, 2019: 2). Bez wiedzy na temat korzyści, ale też zagrożeń, które niesie ze sobą ich zakup, nie będą w stanie wybrać produktu najbardziej dostosowanego do ich potrzeb i możliwości nabywczych. Kryzys na amerykańskim rynku kredytów hipotecznych z 2008 roku pokazał, jak istotnym zagrożeniem może być niedostateczny poziom edukacji finansowej konsumentów. Skutki braku świadomości ekonomicznej przekładają się na pogorszenie sytuacji finansowej gospodarstw domowych i konsekwencje dla stabilności systemu finansowego na całym świecie. Brak dostatecznej wiedzy finansowej ograniczał percepcję konsumentów co do skali podejmowanego ryzyka kre- 
dytowego, co doprowadziło do problemów z obsługą zadłużenia. Kluczową kwestią staje się zatem dostęp do fachowej, rzetelnej i wiarygodnej informacji (www8). Konsekwencją niedostatecznej edukacji w sferze finansowej jest coraz bardziej zauważalne ryzyko wykluczenia finansowego. Definiowane jest jako sytuacja, w której osoba napotyka na trudności w dostępie i/lub w korzystaniu $\mathrm{z}$ usług oraz produktów finansowych w zakresie odpowiadającym jej potrzebom i umożliwiającym jej prowadzenie normalnego życia społecznego (Penczar i in., 2014: 5). Problem ten może dotyczyć wszystkich grup usług finansowych. Szczególnie narażone są gospodarstwa domowe o ograniczonych dochodach i znajdujące się w niekorzystnej sytuacji społecznej. Wykluczenie finansowe stanowi tym samym ważny problem gospodarczy. Ogranicza bowiem potencjał rozwoju rynku finansowego oraz negatywnie oddziałuje na poziom popytu konsumpcyjnego. Zjawisku temu może towarzyszyć wzrost skali obciążeń budżetowych w postaci rosnącego poziomu wypłaty zasiłków społecznych. To kolejny argument świadczący o randze edukacji finansowej. Ogromną rolę w dbaniu o stabilność systemu finansowego odgrywa działalność prowadzona w tym zakresie przez różne instytucje. Organizowane przez NBP oraz PTE konkursy mają zachęcić młodzież do poszukiwania informacji na temat funkcjonowania instytucji i rynków finansowych czy roli pieniądza w gospodarce i jego historii. Szkolenia przygotowywane z myślą o nauczycielach służą poznaniu możliwości wykorzystania technologii informatycznych w edukacji ekonomicznej. W ten sposób zyskują oni dostęp do zasobów pomocnych w rozwijaniu kreatywności, dzięki czemu mogą zaskoczyć swoich uczniów w realizacji zajęć szkolnych, np. w zakresie takich przedmiotów jak: podstawy przedsiębiorczości, wiedza o społeczeństwie, matematyka i doradztwo zawodowe. Pomocne w pracy nauczycieli mogą się okazać dostępne na stronie internetowej NBP scenariusze lekcji. Cennych informacji dostarczają słownik pojęć oraz zmieszczone w zasobach edukacyjnych broszury oraz filmy. Utrwaleniu zdobytej wiedzy może służyć gra ekonoMistrz (www2). Na uwagę zasługuje oferta Centrum Pieniądza im. Sławomira Skrzypka. Celem instytucji działającej przy NBP jest popularyzowanie wiedzy na temat ekonomii i historii pieniądza. Edukacja prowadzona jest w sposób atrakcyjny, przy wykorzystaniu różnorodnych form prezentacji i nowoczesnych technologii.

O roli i wpływie edukacji ekonomicznej na stabilność systemu finansowego świadczyć mogą prowadzone przez NBP badania. Z analizy dokonanej w roku 2014 oraz 2018 wynika, że poprawie uległa wartość wskaźnika IKE (Indeksu Kompetencji Ekonomicznych $)^{6}$. Diagnoza NBP uwidoczniła najniższy zasób wiedzy wśród uczniów szkół podstawowych w porównaniu ze starszą młodzieżą. Pytania, z którymi mierzyli się ankietowani dotyczyły wielu obszarów. Najwięcej

${ }^{6} \mathrm{~W}$ przypadku uczniów klas VI szkoły podstawowej wynosił on $53 \%$, a po 4 latach wzrósł do $57 \%$. W grupie uczniów szkół gimnazjalnych kształtował się na poziomie 56 i 58\%, a wśród licealistów - 63 i $65 \%$. 
trudności sprawiły te dotyczące makroekonomii, ryzyka i otoczenia finansowego. Raporty NBP zwracają uwagę na konieczność zapewnienia młodzieży dostępu do wiarygodnych i zróżnicowanych źródeł informacji oraz powiązanie ich z obszarami zainteresowań uczniów, np. sport, muzyka, gry komputerowe, podróże, moda. Programy edukacyjne, mające na celu pogłębienie wiedzy z zakresu ekonomii, finansów oraz gospodarki, powinny przede wszystkim charakteryzować się użytecznością, tj. możliwością wykorzystania nabytych przez uczniów umiejętności w życiu codziennym (www1).

Zorganizowane przez autorkę rozmowy pokazują, że młodzież jest świadoma wagi ekonomii na co dzień. Dzieciom, zarówno tym w przedszkolach, jak i w szkołach, nieobce są fachowe pojęcia. Bacznie obserwują swoich rodziców, którzy prowadząc z nimi rozmowy o budżecie domowym, kontrolując ich wydatki, zachęcając do oszczędzania, mogą rozszerzać zakres ich wiedzy oraz kształtować odpowiednie umiejętności. Młodzież często podkreśla, że pierwszym źródłem informacji oraz wzorem do naśladowania są najbliżsi członkowie rodziny. Nastolatki chętnie korzystają $z$ dedykowanych im produktów finansowych ${ }^{7}$ (własne konto bankowe i dołączona do niego karta) oraz sprawnie poruszają się po świecie mobilnej bankowości. Transakcji w sklepach dokonują blikiem, a przelewy między sobą wykonują na telefon. Nie wszyscy natomiast rozumieją zawiłości wyliczania podatków, wyliczania kosztów obsługi kredytu czy funkcjonowania gospodarki. W tych obszarach działalność edukacyjna może przynieść pożądane efekty, podnieść poziom wiedzy uczniów oraz wzbogacić ich w umiejętności przydatne w życiu dorosłym.

W wywiadach nauczyciele podkreślali wagę swojego udziału w różnego rodzaju warsztatach, dzięki którym zyskują dostęp do ciekawych metod nauczania, pakietów materiałów edukacyjnych i ćwiczeń interaktywnych. Mają świadomość konieczności modyfikacji programów nauczania w taki sposób, by stały się dla uczniów atrakcyjne, użyteczne i aktualne. Rozmówcy autorki zwracali uwagę na możliwość powszechnego stosowania testów kompetencji (zbliżonych do tych, wykorzystywanych przez NBP, na podstawie których został wyznaczony IKE). W ten sposób można byłoby na bieżąco monitorować stan wiedzy uczniów i kłaść ciężar edukacji na te obszary, w których zidentyfikowano istotne braki. Znaczenie w/w czynników, mogących służyć poprawie jakości i skuteczności kształcenia akcentowali w swoich badaniach m.in. McCormick (2009: 73-75), Mandell i Klein (2007: 109-114).

${ }^{7}$ Ponad $60 \%$ uczniów szkół podstawowych oraz ponad 80\% uczniów szkół ponadpodstawowych posiada pieniądze na swoje wydatki. Około 30\% uczniów ma własne oszczędności. 


\section{PODSUMOWANIE}

Przeprowadzone badania pozwoliły na pozytywną weryfikację przyjętej hipotezy oraz umożliwiły uzyskanie odpowiedzi na postawione pytanie badawcze. Studia literatury ukazują jak złożonym i wieloelementowym układem jest system finansowy. Dbałość o jego rozwój ma istotne znaczenie z punktu widzenia gospodarki. Sprawnie działający system finansowy jest źródłem płynności, mobilizuje oszczędności i zapewnia ich efektywną alokację oraz tworzy szansę na redukcję ryzyka podejmowanego przez indywidualnych inwestorów. Zapewnienie jego stabilności jest niezmiernie ważnym, ale i niełatwym zadaniem. Podlega ona wpływowi ze strony różnych czynników (wewnętrznych i zewnętrznych). W wielu publikacjach zwraca się uwagę na kwestię odpowiedniej architektury systemu nadzoru, konieczność narzucenia dyscypliny rynkowej i wprowadzenia odpowiednich regulacji zmierzających do większej dbałości o płynność różnych podmiotów finansowych (Bllis and Flanery, 2002: 361-96; www8). Należy jednak mieć na uwadze, że działalność edukacyjna jest jednym z tych determinantów, które również mogą korzystnie oddziaływać na stabilne funkcjonowanie systemu finansowego. Oferta szkół oraz innych instytucji, zajmujących się kształceniem w zakresie ekonomii i finansów, powinna być dostosowana do wieku uczniów, zapewniać dostęp do wiarygodnych informacji, wykorzystywać nowoczesne metody kształcenia, a także łączyć wiedzę ekonomiczną z jej praktycznym zastosowaniem. Zaproponowane zmiany (na podstawie uzyskanych wyników badań) mogą przyczynić się do podniesienia jakości i skuteczności edukacji ekonomicznej młodzieży.

Analiza raportów NBP oraz odpowiedzi respondentów prowadzą do wniosku, że kształtowanie właściwych postaw i kompetencji poszczególnych uczestników rynku finansowego może zmniejszać zagrożenie wykluczeniem finansowym i zapobiegać brakowi zaangażowania w sprawy finansowe niektórych konsumentów. Od znajomości podstawowych zagadnień ekonomicznych oraz świadomości potencjalnych zagrożeń zależy trafność podejmowanych w życiu dorosłym decyzji. Wyedukowany nabywca zrozumie zapisy umowy, będzie znał swoje prawa i obowiązki, a tym samym ma większą szansę na dokonanie właściwych wyborów. Dysponowanie wiedzą nie daje oczywiście 100\% gwarancji na podjęcie słusznej decyzji, ale w istotny sposób może minimalizować potencjalne ryzyko. Nieprzemyślane, niewłaściwie przeprowadzone transakcje finansowe mogą negatywnie wpływać na zdolność kredytową konsumentów, stwarzać zagrożenie popadnięcia $\mathrm{W}$ spiralę zadłużenia. W dalszej perspektywie może się to odbić na kondycji poszczególnych instytucji finansowych, których są klientami, co zaburzy stabilność systemu finansowego. 


\section{BIBLIOGRAFIA}

Anginer, D., Demirgüç-Kunt, A. and Zhu, M. (2014). How Does Competition Affect Bank Systemic Risk? Journal of Financial Intermediation, 23(1).

Bliss, R.R. and Flannery, M.J. (2002). Market Discipline in the Governance of US Bank Holding Companies: Monitoring vs. Influencing. Review of Finance, 6(3).

Czekaj, J. (2008). Rynki, instrumenty $i$ instytucje finansowe. Warszawa: Wydawnictwo Naukowe PWN.

Dębski, W. (2010). Rynek finansowy i jego mechanizmy. Podstawy teorii i praktyki. Warszawa: PWN.

Frączek, B. (2013). Obszary badań w zakresie poziomu wiedzy i edukacji finansowej społeczeństwa w Polsce i na świecie. Zeszyty Naukowe Uniwersytetu Ekonomicznego w Katowicach, 173/1.

Frisancho, V. (2019). The impact of Financial Education for Youth. IDB-WP-1038, http://dx.doi.org/10.18235/0001791.

Howells, P. and Bain, K. (1998). The Economics of Money, Banking and Finance. A European Text. London: Addison Wesley Longman.

Husiatyńska, R. (2018). Wpływ edukacji finansowej na świadomość podejmowanych decyzji finansowych przez społeczeństwo. Europa Regionum, 1, XXXIV.

Jajuga, K., Kuziak, K. i Markowski, P. (1998). Inwestycje finansowe. Wrocław: Wydawnictwo Akademii Ekonomicznej we Wrocławiu.

Janc, A. (2004). Modern banking in transition economies of Central and Eastern Europe. Poznań: The Poznan University of Economics.

Kuchciak, I. (2013). Kreowanie świadomości finansowej wyzwaniem konkurencyjności w niesprzyjającym otoczeniu. Zarządzanie i Finanse, 4/4.

Mandell, L. and Klein, L. (2007). Motivation and financial literacy. Financial Services Review, 16.

Matysek-Jędrych, A. (2007). System finansowy - definicje i funkcje. Bank i Kredyt, 10.

McCormick, M. (2009). The Effectiveness of Youth Financial Education. Journal of Financial Counselling and Planning, 20(1).

Merton, R.C. and Bodie, Z. (1995). A Conceptual Framework for Analyzing the Financial Environment. W: D.B. Crane, K.A. Froot, S.P. Mason, A.F. Perold, R.C. Merton, Z Bodie., E.R. Sirri, P. Tufano, The Global Financial System. A Functional Perspective. Boston: Harvard Business School Press.

Owsiak, S. (2015). Finanse. Warszawa: PWN.

Penczar, M., red. (2014). Rola edukacji finansowej w ograniczaniu wykluczenia finansowego. Gdańsk: IBnGR.

Pietrzak, B., Polański, Z. i Woźniak, B., red. (2016). System finansowy w Polsce. Warszawa: PWN.

Rose P.S. (1992). Money and Capital Markets. The Financial System in an Increasingly Global Economy. Boston: Texas University.

Stiglitz J.E. (1992). The Design of Financial Systems for the Newly Emerging Democracies of Eastern Europe. W: C. Clague, G.C. Rausser, ed., The Emergence of Market Economies in Eastern Europe. Cambridge: Blackwell Publishers.

Świecka, B. (2018). Kompetencje finansowe i edukacja finansowa. Ujęcie teoretyczne i praktyczne. Rozprawy Ubezpieczeniowe. Konsument na rynku uslug finansowych, 27.

Tyrell, M., Schmidt, R.H. (2001). Pension Systems and Financial Systems in Europe: A Comparison form the Point of View of Complementarity. Working Paper Series: Finance \& Accounting, 65, Frankfurt am Main: J.W. Goethe Universität.

Zombirt, J. (2011). Mechanizmy rynku wewnętrznego Unii Europejskiej. Warszawa: Difin.

[www1] www.nbp.pl/edukacja/badania/diagnoza-stanu-wiedzy-i-swiadomosci-ekonomicznejdzieci-mlodziezy.pdf [dostęp 25.11.2020].

[www2] www.nbp.pl/home.aspx?f=/edukacja/index.html [dostęp 20.11.2020]. 
[www3] www.nbp.pl/home.aspx?f=/akty_prawne/akty_prawne.html [dostęp 08.11.2020]. [www4] www.nbp.pl/home.aspx?f=/o_nbp/o_nbp.html [dostęp 10.11.2020].

[www5] www.nbp.pl/home.aspx?f=/o_nbp/informacje/stabilnosc_finansowa.html [dostęp 14.11.2020].

[www6] www.nbp.pl/home.aspx?f=/systemfinansowy/stabilnosc.html [dostęp 14.11.2020].

[www7] https://www.worldbank.org/en/publication/gfdr/gfdr-2016/background/financial-stability [dostęp 06.06.2021].

[www8] Global Financial Development Report, World Bank 2019/2020; https://openknowledge.worldbank.org/bitstream/handle/10986/32595/9781464814471.pdf [dostęp 08.06.2021]. 